DOI: $10.1007 / \mathrm{s} 00454-001-0017-\mathrm{z}$

\title{
Index to Volume 25
}

Agarwal, P. K., Halperin, D., and Pollack, R.: Guest Editors' Foreword

AlliLI, M., and KACZYNSKI, T.: Geometric Construction of a Coboundary of

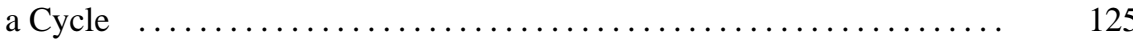

Aronov, B., and DEY, T. K.: Polytypes in Arrangements ..............

Aronov, B., Efrat, A., HALPERIN, D., and ShARIR, M.: On the Number of Regular Vertices of the Union of Jordan Regions $\ldots \ldots \ldots \ldots \ldots \ldots$.

Aronov, B., Goodman, J. E., Pollack, R., and Wenger, R.: A Helly-Type Theorem for Hyperplane Transversals to Well-Separated Convex Sets

BÁRÁNY, I., and MATOUŠEK, J.: Simultaneous Partitions of Measures by $k$-Fans

BAREQuet, G., Dickerson, M. T., and Goodrich, M. T.: Voronoi Diagrams for Convex Polygon-Offset Distance Functions $\ldots \ldots \ldots \ldots \ldots \ldots \ldots$

BARVINOK, A.: A Remark on the Rank of Positive Semidefinite Matrices Subject to Affine Constraints $\ldots \ldots \ldots \ldots \ldots \ldots \ldots \ldots \ldots \ldots \ldots \ldots \ldots \ldots \ldots \ldots \ldots \ldots \ldots$

BAues, O., and PeYerimhoff, N.: Curvature and Geometry of Tessellating

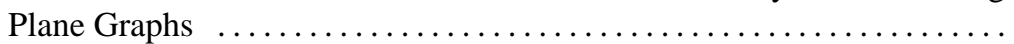

BesPAMYATNIKH, S.: An Efficient Algorithm for the Three-Dimensional Di-

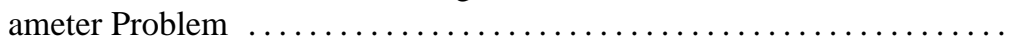

BLIND, G., and BLIND, R.: Isoperimetric Quotients for a Decomposed Convex

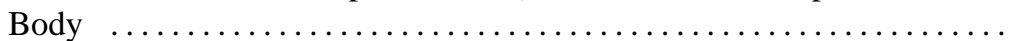

BLIND, R.: see Blind, G. . . . . . . . . . . . . . . . . . . . . . .

BOCHIŞ, D., and SANTOS, F.: On the Number of Facets of Three-Dimensional Dirichlet Stereohedra, I: Groups with Reflections $\ldots \ldots \ldots \ldots \ldots \ldots$

BÖRÖCZKY, K: About the Error Term for Best Approximation with Respect to the Hausdorff Related Metrics $\ldots \ldots \ldots \ldots \ldots \ldots \ldots \ldots \ldots . \ldots \ldots$

BROCK Williams, G.: Approximation of Quasisymmetries Using Circle

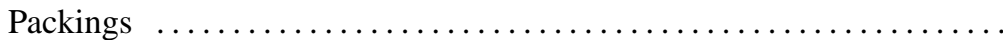

Chazelle, B., and Lvov, A.: The Discrepancy of Boxes in Higher Dimension

Cheng, C. C., Duncan, C. A., Goodrich, M. T., and Kobourov, S. G.: Drawing Planar Graphs with Circular Arcs ................

Cheng, H.-L., Dey, T. K., Edelsbrunner, H., and Sullivan, J.: Dynamic

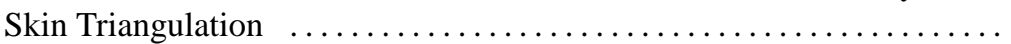

COXETER, H. S. M., and GRÜNBAUM, B.: Face-Transitive Polyhedra with Rectangular Faces and Icosahedral Symmetry $\ldots \ldots \ldots \ldots \ldots \ldots \ldots$

DEY, T. K.: see Aronov, B. . . . . . . . . . . . . . . . . . . . . . .

DEY, T. K.: see Cheng, H.-L. . . . . . . . . . . . . . . . . . . . . . . .

DICKERSON, M. T.: see Barequet, G. . . . . . . . . . . . . . . . . . .

Duncan, C. A.: see Cheng, C. C. . . . . . . . . . . . . . . . . . . . .

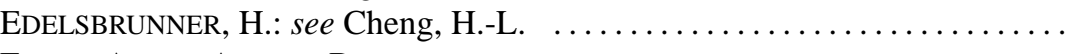

EFRAT, A.: see Aronov, B.

ELSER, V.: Crystallography and Riemann Surfaces $\ldots \ldots \ldots \ldots \ldots \ldots \ldots$

EsCH, J., and Rogers, T. D.: The Screensaver Map: Dynamics on Elliptic Curves Arising from Polygonal Folding 
GÄRTNER, B., and Welzl, E.: A Simple Sampling Lemma: Analysis and Applications in Geometric Optimization .................... 569

GoODMAN, J. E.: see Aronov, B. . . . . . . . . . . . . . . . . . . . . . . . . . . 507

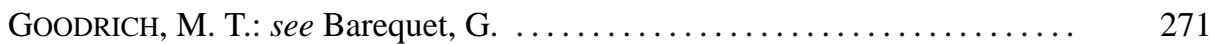

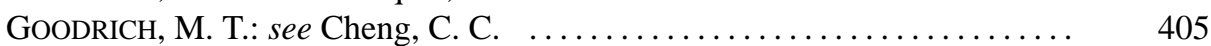

GrünBAUM, B.: see Coxeter, H. S. M. . . . . . . . . . . . . . . . . . . 163

Guibas, L., Hershberger, J., Suri, S., and Zhang, L.: Kinetic Connectivity

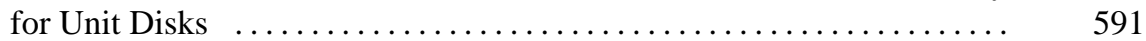

Hales, T. C.: The Honeycomb Conjecture $\ldots \ldots \ldots \ldots \ldots \ldots \ldots \ldots \ldots \ldots \ldots$

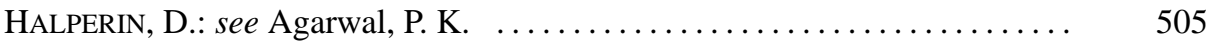

HALPERIN, D.: see Aronov, B. . . . . . . . . . . . . . . . . . . . . . . 203

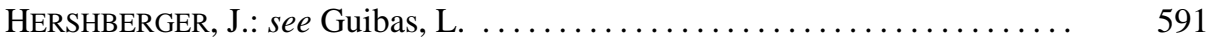

HLINĚNÝ, P.: An Addition to Art Galleries with Interior Walls . . . . . . . . 311

Holley, R., Malitz, J., and Malitz, S.: An Approach to Hierarchical Clustering via Level Surfaces and Convexity $\ldots \ldots \ldots \ldots \ldots \ldots \ldots \ldots \ldots$

ISMAILESCU, D.: Inequalities between Lattice Packing and Covering Densities of Centrally Symmetric Plane Convex Bodies ................. 365

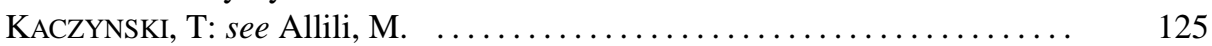

Kobourov, S. G.: see Cheng, C. C. . . . . . . . . . . . . . . . . . . . . 405

LEE, JEONG-Yup, and MoOdY, R. V.: Lattice Substitution Systems and Model

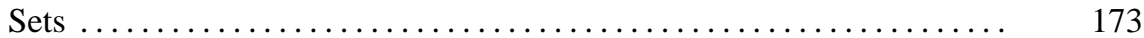

Lvov, A.: see Chazelle, B. ............................ 519

MAKAI, E., VREĆICA, S., and ŽIVAlJEVIĆ, R.: Plane Sections of Convex Bodies of Maximal Volume $\ldots \ldots \ldots \ldots \ldots \ldots \ldots \ldots \ldots \ldots \ldots \ldots \ldots \ldots \ldots \ldots \ldots$

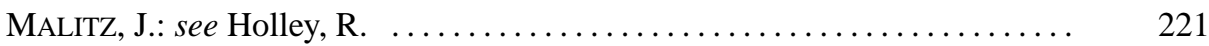

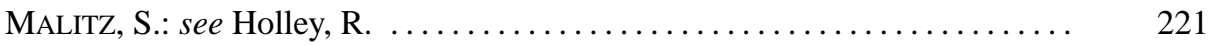

MATOUŠEK, J.: On Directional Convexity $\ldots \ldots \ldots \ldots \ldots \ldots \ldots \ldots \ldots \ldots \ldots$

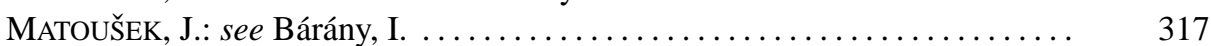

MoODY, R. V.: see Lee, Jeong-Yup $\ldots \ldots \ldots \ldots \ldots \ldots \ldots \ldots \ldots \ldots \ldots \ldots \ldots$

MORRIS, JR., W. D.: Convex Dimension of Locally Planar Convex Geometries $\quad 85$

PACH, J., and PINCHASI, R.: On the Number of Balanced Lines . . . . . . . . 611

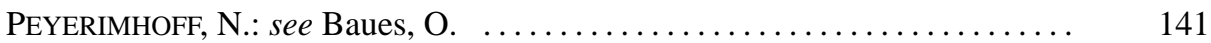

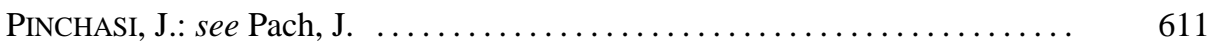

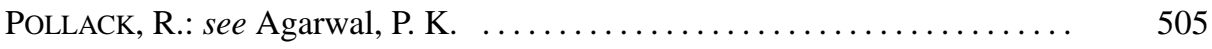

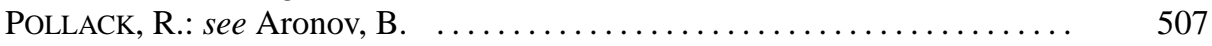

Richter, C.: Simple Paradoxical Replications of Sets $\ldots \ldots \ldots \ldots \ldots \ldots \ldots .65$

ROGERS, T. D.: see Esch, J. .............................. 477

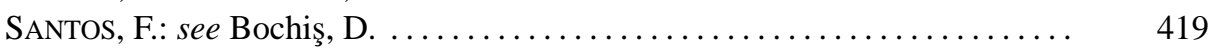

SHARIR, M.: see Aronov, B. . . . . . . . . . . . . . . . . . . . . . . . . . . 203

SOlYMOSI, J., and TóTH, Cs. D.: Distinct Distances in the Plane ........ 629

Sullivan, J.: see Cheng, H.-L. . . . . . . . . . . . . . . . . . . . . . . . . 525

SURI, S.: see Guibas, L. . . . . . . . . . . . . . . . . . . . . . . 591

Tóth, Cs. D.: see Solymosi, J. . . . . . . . . . . . . . . . . . . . . . . . 629

VrećicA, S. T., and Živaljević, R. T.: Conical Equipartitions of Mass

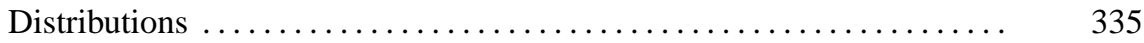

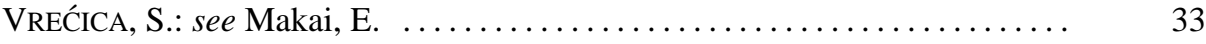


WELZL, E.: Entering and Leaving $j$-Facets $\ldots \ldots \ldots \ldots \ldots \ldots \ldots \ldots \ldots \ldots \ldots \ldots \ldots$

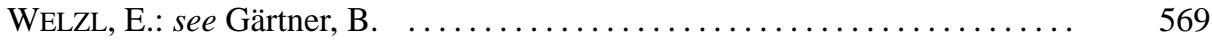

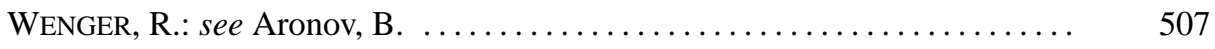

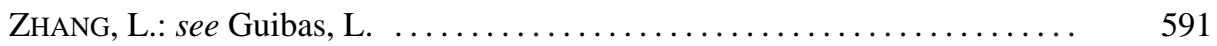

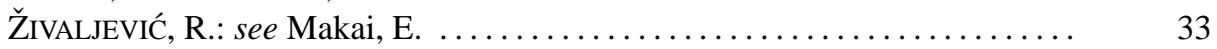

ŽIVALJEVIĆ, R. T.: see Vrećica, S. T. ....................... 335 
The exclusive copyright for all languages and countries, including the right for photomechanical and any other reproductions, also in microform, is transferred to the publisher.

The use of registered names, trademarks, etc., in this publication does not imply, even in the absence of a specific statement, that such names are exempt from the relevant protective laws and regulations and therefore free for general use.

Printed in the United States of America (c) 2001 by Springer-Verlag New York Inc. 